\title{
Geochemistry of Groundwaters in the Utsunomata Landslide Area, Maki Village, Higashikubiki District, Niigata Prefecture
}

\author{
XU Huilong*, Yasue ŌKI**, Osamu SATO** and Hideki WATANABE***
}

概 要

宇津俣地すべり地帯は新潟県南西部に位置する。地すべり地帯地下水の水温・水質調査を実施したところ, 陰イ オンと陽イオンの組み合わせから $\mathrm{Ca}-\mathrm{HCO}_{3}$ 型, $\mathrm{Na}-\mathrm{HCO}_{3}$ 型, $\mathrm{Ca}-\mathrm{SO}_{4}$ 型, $\mathrm{Na}-\mathrm{SO}_{4}$ 型, $\mathrm{Ca}-\mathrm{SO}_{4}-\mathrm{HCO}_{3}$ 型, $\mathrm{Na}-\mathrm{SO}_{4}$ $\mathrm{HCO}_{3}$ 型, $\mathrm{Na}-\mathrm{HCO}_{3}-\mathrm{Cl}$ 型と $\mathrm{Na}-\mathrm{Cl}-\mathrm{HCO}_{3}$ 型など 8 種類の地下水が認められた。前 6 タイプの地下水が水一岩石相 互作用によって形成された浅い地下水である。塩素イオン濃度の高い地下水, 特に高濃度の $\mathrm{Na}-\mathrm{Cl}-\mathrm{HCO}_{3}$ 型と $\mathrm{Na}$ $-\mathrm{HCO}_{3}-\mathrm{Cl}$ 型地下水は活断層にそって分布していることが確認された。これらのタイプの地下水は活断層の亀裂帯 にそって湧出しているジオプレッシャー型熱水と浅い地下水とが混合することによって生じたものである。水温・ 水質異常地帯は活断層の存在を強く支持している。新第三紀の厚い泥岩層の下に貯留されているジオプレッシャー 型地下熱水は活断層の亀裂帯に沿って上昇して, 地すべり土塊の帯水層に達すれば, 間隙水圧と地下水水位の上昇 をもたらし地すべりの発生を誘発するものと推定される。活動的な地すべり地域においての地下水の電気伝導度と 主要な成分濃度は高い值を示していて, 非地すべり地帯の地下水より 10-50 倍高い。活動している地すべり地域で は地下水は高濃度の $\mathrm{Na}-\mathrm{Cl}-\mathrm{HCO}_{3}$ 型, $\mathrm{Na}-\mathrm{HCO}_{3}-\mathrm{Cl}$ 型と $\mathrm{Na}-\mathrm{SO}_{4}$ 型が主なものである。安定あるいは準安定的な 地すべり地域では地下水は低濃度の $\mathrm{Ca}-\mathrm{HCO}_{3}$ 型, $\mathrm{Na}-\mathrm{HCO}_{3}$ 型と $\mathrm{Ca}-\mathrm{SO}_{4}$ 型で特徴づけられている。 キーワード: 地すベり活動, 地下水, ジオプレッシャー型熱水系*, ジオプレッシャー型地すべり*, 活断層

\section{Introduction}

Behavior of groundwater is one of the principal factors affecting generation of landslide, Ōki et al. ${ }^{1}$ pointed out that destructive earthquakes and landslides were triggered by activity of geopressured hydrothermal system in the Northern Fossa Magna region. Billard et al. ${ }^{2}$ discussed the role of chemical weathering by groundwater in triggering landslide in the loess area of Gansu Province, China. We can expect that geochemical studies of groundwater in landslide will provide important information for prevention of landslide and for earthquake prediction in the large-scale geopressured type landslide area.

Due to strong Neogene tectonic movement, the slightly consolidated Tertiary formations had been

* Graduate School of Science and Technology, Niigata University

** Research Institute for Hazards in Snowy Areas, Niigata University

**** Niigata Branch,Nissaku Co. Ltd. deformed as series of NNE trending folds and faults in the Late Cenozoic Niigata sedimentary basin. The seismic activity in this sedimentary basin is conspicuous, destructive earthquakes often associated with obvious anomalies of groundwater, particularly along the Shinano seismic zone ${ }^{3,4)}$. Many landslides occurred and often associated with thermal and mineral springs in the Niigata sedimentary basin. Several thermal springs and gas springs issue from fractures of the Utsunomata landslides. The generation of these landslides would be related to activity of geopressured hydrothermsl system.

Groundwater in the active landslide is characterized by the high electrical conductivity. As the landslide gets stable, the electrical conductivity and concentrations of components of groundwater become low. The quality of groundwater can well reflect geological and hydrologic environments of landslide and also indicate degree of the process of water-rock interaction. 


\section{Outline of Geology and Landslide Activ- ity}

Utsunomata locates in the southwesten border of the Higashikubiki Hills, Niigata Prefecture and belongs to the southwestern part of the Late Cenozoic Niigata sedimentary basin, in which the Middle Miocene to the Early Pleistocene marine to non marine sediments were accumulated. It is characterized by NNE-SSW trending folds and faults ${ }^{5}$. Main structures are the Nagakurayama anticline and the Takaba fault as shown in Fig. 1. The elevation is about $400-740 \mathrm{~m}$. The bedrock of the Utsunomata area is the Taruda formation of Late Miocene, which is mostly composed of interbedded black mudstone and sandstone and massive mudstone. The Matsunoyama Tuff composed of dacitic crystal pumice tuff is intercalated in the middle horizon of the Taruda formation. A gas spring and some thermal springs are yielded from the Taruda formation in the study area.

Because the study area locates at the intersection of the Takaba fault and the Nagakurayama anticline, the bedrock was deformed and broken. Geopressured thermal water issues through fractures formed in the Taruda formation as a source of replenishment of groundwater. For this reason, many landslides might be triggered by increasing of liquid pressure of the destructed mass in this area. Main landslides are the Happoukuchi, the Utsunomata and the Ishikura landslides (Fig. 2). Prevention engineerings for these landslides were carried out by the Chisan Division and the Sabo Division, Niigata Prefecture Government.

The Happoukuchi landslide occurred in November, 1992. Its elevation is about $560 \mathrm{~m}$ in the headscarp and $400 \mathrm{~m}$ in the front part near the Yunokawa river. The scarp of landslide is $20-30$ meters in height. The fresh bedrock is exposed and slickensides well developed in here. The landslide shows as a horseshoe form with $700 \mathrm{~m}$ in length and $40-100 \mathrm{~m}$ in width. The plane of landslide with about $10^{\circ}-20^{\circ}$ dips NNW direction and changes to $\mathrm{N} 50^{\circ} \mathrm{W}$ at $480 \mathrm{~m}$ in elevation. The bedrock is the Taruda formation. Many cracks developed in this formation and were filled by calcite viens. The colluvial deposits of landslide is about $8-15$ meters in thickness.

The Utsunomata landslide is divided into four blocks named as A,B,C and D block. From the early days of this century, many small scale collapses

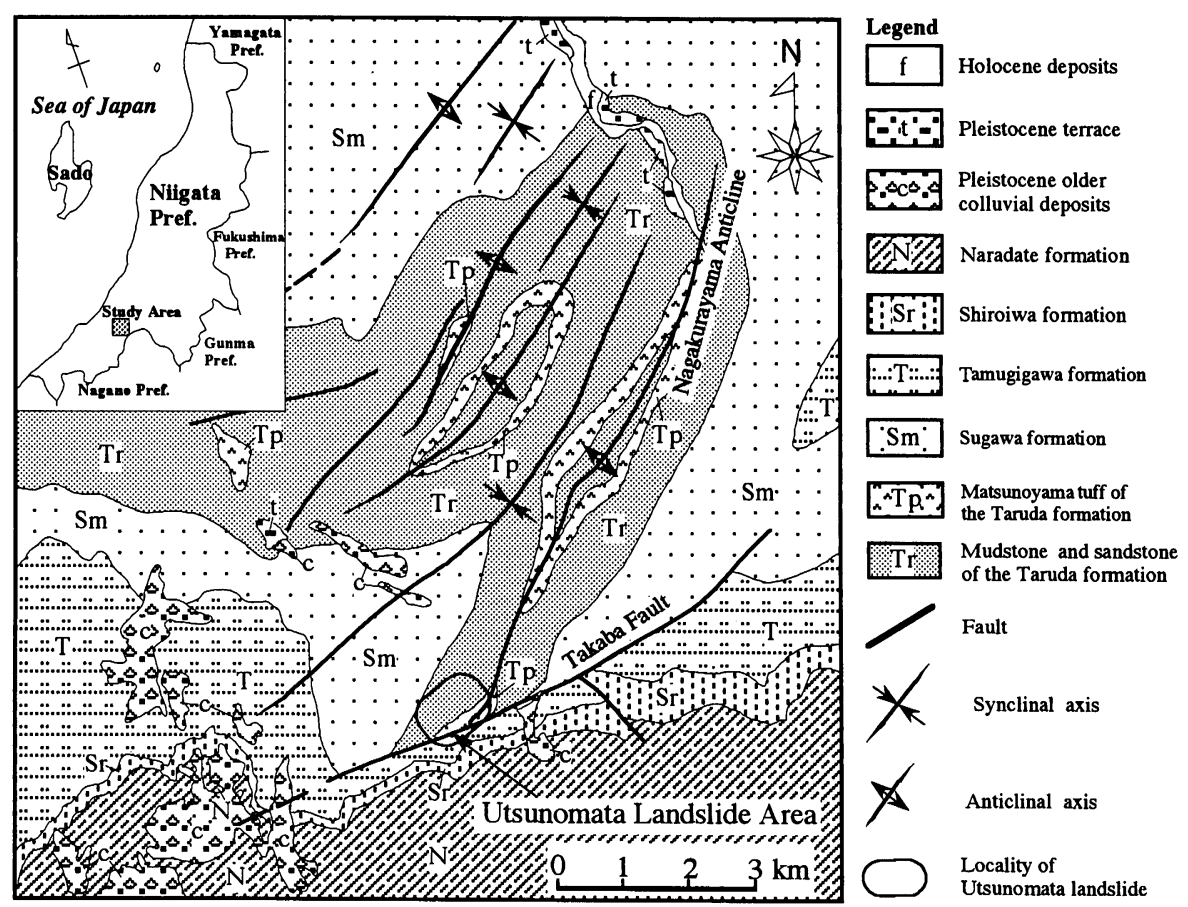

Fig. 1 Geological map of Utsunomata, Niigata Prefecture (after Keiji Takeuchi and Hirokazu Kato, 1993) 


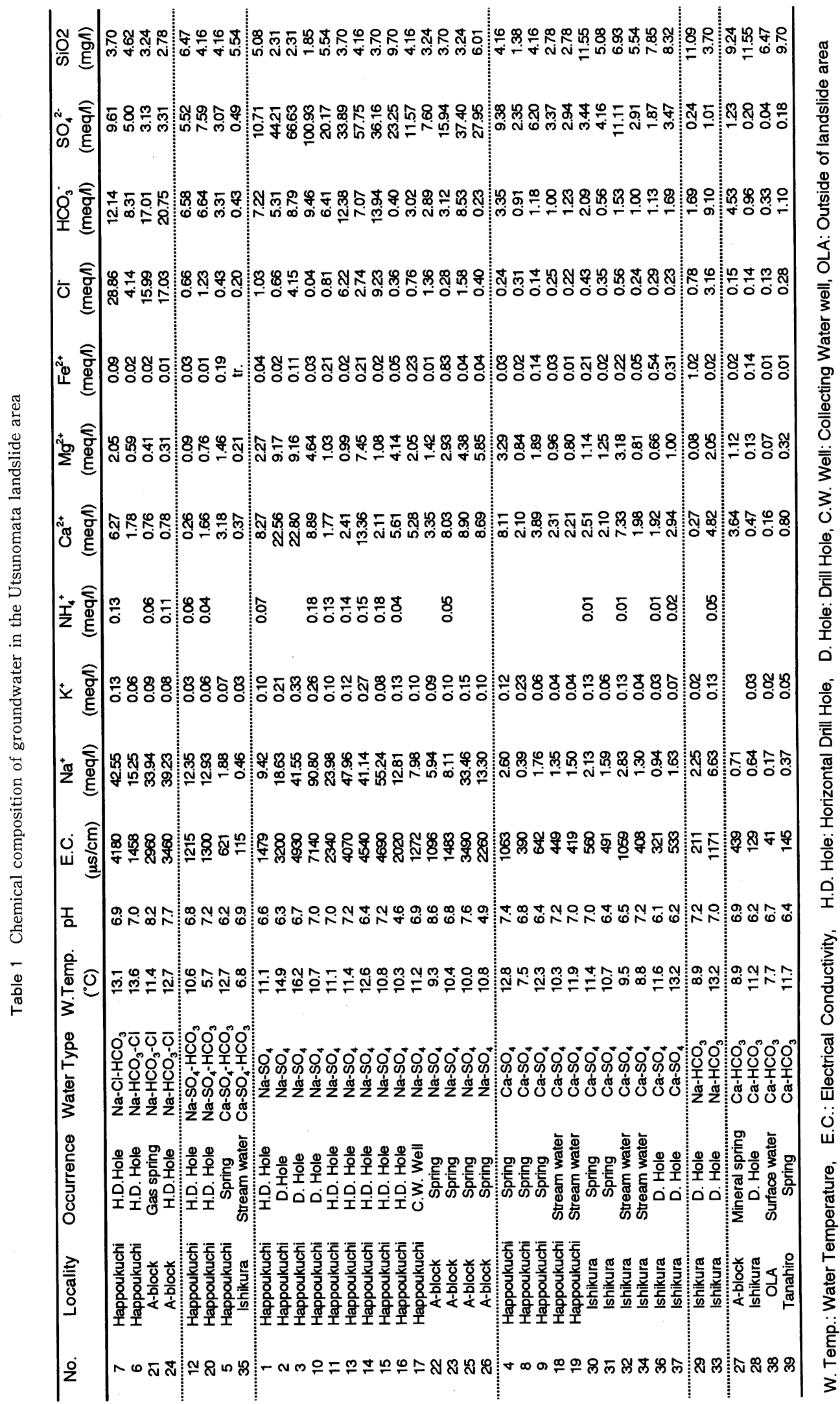




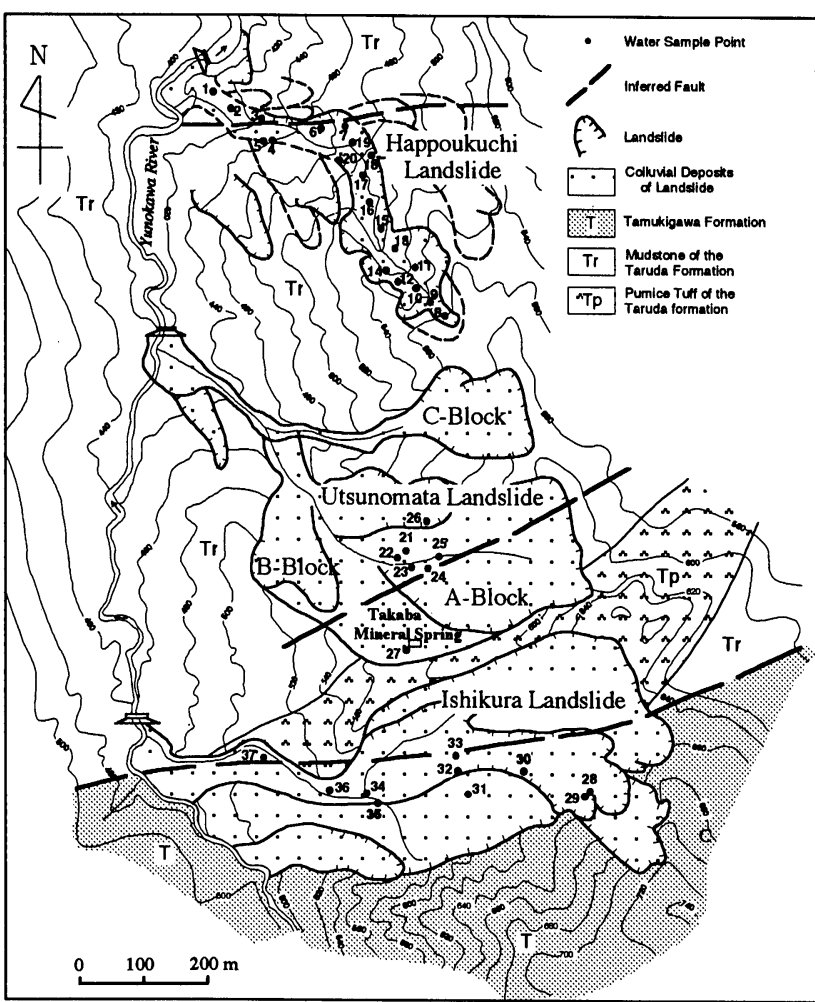

Fig. 2 Geological map showing the distribution of water samples in the Utsunomata landslide area stable as a metastable.

\section{Groundwater Sampling}

The grounwater samples were collected from horizontal drainage holes, collecting water wells, drill holes, all which were prepared by the prevention engineering by the government, natural springs and steamwaters in the Happoukuchi, the Utsunnomata and the Ishikura landslides. Six surface water samples were collected from steams in these landslides and their surrounding area. The water sampling sites are shown in Fig. 2.

(a) Happoukuchi Landslide

Twenty samples were collected from this landslide. Ten samples were collected from horizontal drainage holes, 3 samples from drill holes, one sample from collecting water well, 4 samples are natural springs and 2 samples are streamwaters.

(b) Utsunomata Landslide

Seven water samples were collected from this landslide, among them 4 samples are natural springs, the others are horizon-

occurred intermittently. In the A block, landslide occurred two times in 1987 and 1989, respectively. It is $450 \mathrm{~m}$ in length and $200 \mathrm{~m}$ in width. The bedrock is mudstone and pumice tuff of the Taruda formation. The slope of landslide plane is slightly steep in the headscarp and the front as about $15^{\circ}-20^{\circ}$, but the rest is in the central part with gentle slope. The colluvial deposit is about $18-36 \mathrm{~m}$ in thickness.

The Ishikura landslide occurred in 1952. Deformation of the mass was slowly reactivated and caused again geofracture in 1988. This landslide is $800 \mathrm{~m}$ in length and $150-250 \mathrm{~m}$ in width. The slip plane with about $10^{\circ} \mathrm{dip}$ is buried $15-20 \mathrm{~m}$ in depth. The bedrock is dark grey mudstone and grey dacitic pumice tuff of the Taruda formation and the Tamugigawa formation.

In the order of landslide activity, the Happoukuchi landslide is the most recent one, the prevention engineering of landslide movement was finished in 1992. The Utsunomata landslide occurred since 1985 and is still continuously active. The Ishikura landslide is old one. This landslide is now believed to be getting tal drainage hole water, gas spring and mineral springs respectively.

(c) Ishikura Landslide

Ten samples were collected from this landslide, 5 samples were collected from drill holes, 2 samples are natural spring and 3 samples are steamwater.

\section{Chemical characteristics of ground- waters and their geneses}

Temperature, $\mathrm{pH}$ and electrical conductivity of groundwater were measured at the sampling spots, $250 \mathrm{ml}$ water samples for laboratory analyses and $5 \mathrm{ml}$ samples for $\mathrm{Fe}^{2+}$ and $\mathrm{SiO}_{2}$ color metric determination were prepared in the field. The concentrations of $\mathrm{Na}^{+}, \mathrm{K}^{+}, \mathrm{NH}_{4}{ }^{+}, \mathrm{Ca}^{2+}, \mathrm{Mg}^{2+}, \mathrm{Cl}^{-}, \mathrm{SO}_{4}{ }^{2-}$ and $\mathrm{NO}_{3}{ }^{-}$ were analyzed by ion chromatography in the laboratory. $\mathrm{Fe}^{2+}$ was determined by the Ophenanthoroline colorimetric method and $\mathrm{SiO}_{2}$ contents were determined by the molybdosilicate colorimetric method. Alkalinity was determined by titrating with acid down to $\mathrm{pH}$ of about 4 .

The chemical compositions of groundwaters are 


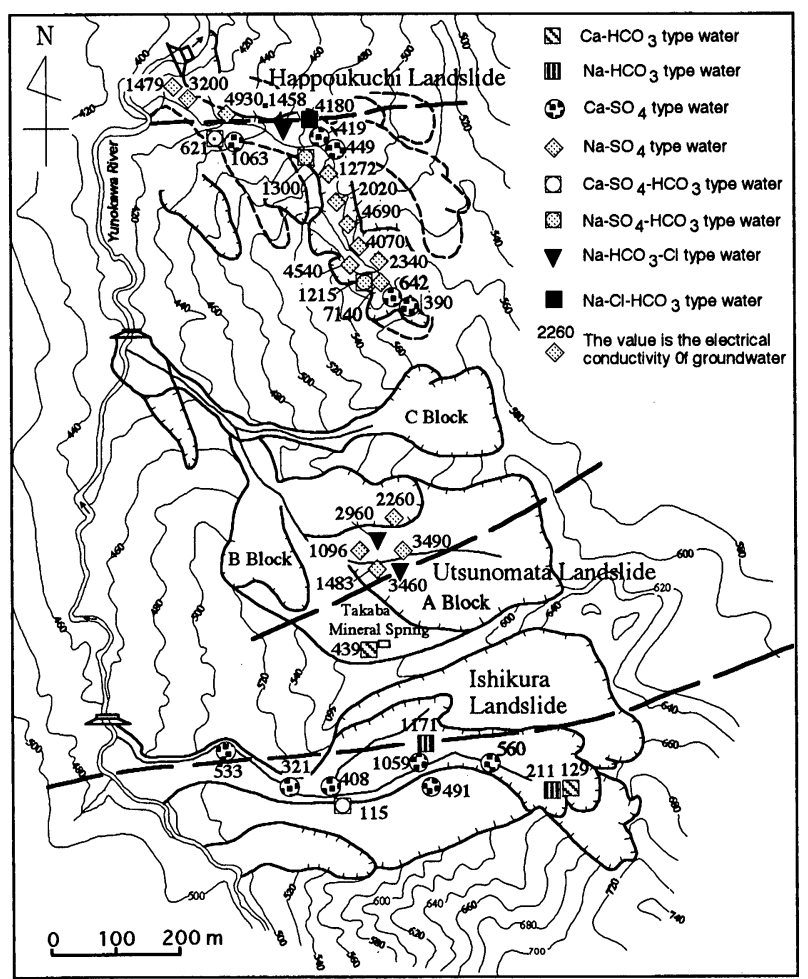

Fig. 3 Distribution of groundwater type in the Utsunomata landslide area, Niigata Prefecture

given in Table 1 and the distribution of the groundwater type is shown in Fig. 3.

\subsection{Groundwater related to geopressured hydroth- ermal system}

$\mathrm{Na}-\mathrm{HCO}_{3}-\mathrm{Cl}$ type and $\mathrm{Na}-\mathrm{Cl}-\mathrm{HCO}_{3}$ type waters are recognized at the central part of the Happoukuchi landslide and A-block of the Utsunomata lamdslide. The electrical conductivities of theses groundwaters range from $1,458 \mu \mathrm{S} / \mathrm{cm}$ to $4,180 \mu \mathrm{S} / \mathrm{cm}$. $\mathrm{Na}^{+}$is dominant cation with concentration of 15.25-42.55 meq/1 and makes up $83-97 \%$ of total cations. $\mathrm{Cl}^{-}$ concentration is high as $28.86 \mathrm{meq} / 1$ and $57 \%$ of total anions in $\mathrm{Na}-\mathrm{Cl}-\mathrm{HCO}_{3}$ type water. $\mathrm{HCO}_{3}{ }^{-}$concentration is $8.31-20.75 \mathrm{meq} / 1$ and accounts for $47-50 \%$ of total anions in $\mathrm{Na}-\mathrm{NCO}_{3}-\mathrm{Cl}$ type waters in which $\mathrm{Cl}^{-}$ concentrations are 4.14-17.03 meq/1.

$\mathrm{Cl}^{-}$concentrations of $\mathrm{Na}-\mathrm{HCO}_{3}-\mathrm{Cl}$ type and $\mathrm{Na}-\mathrm{Cl}$ $-\mathrm{HCO}_{3}$ type waters are about 4 to 28 times higher than the mean's of the shallow groundwaters. Ōki et al. ${ }^{1}$ pointed out that a geopressured hydrothermal system exists widely in the Northern Fossa Magna region at several kilometers deep closely associated with petroleum and natural gas. The geopressured thermal water is characterized by $\mathrm{Na}-\mathrm{Cl}$ type water, which issues from deep through active faults. $\mathrm{Na}-\mathrm{Cl}$ $-\mathrm{HCO}_{3}$ type and $\mathrm{Na}-\mathrm{HCO}_{3}-\mathrm{Cl}$ type waters are fromed by mixing between this geopressured thermal water and shallow meteoric waters. When geopressured thermal water pours up from deep to shallow, it will mix with shallow groundwater. This mixing function causes the increase of $\mathrm{Cl}^{-}$ content in the groundwater and forms such mixing type groundwaters as $\mathrm{Na}-\mathrm{Cl}-\mathrm{HCO}_{3}$ and $\mathrm{Na}-\mathrm{HCO}_{3}-\mathrm{Cl}$ waters

\subsection{Shallow grondwater}

(a) $\mathrm{Ca}-\mathrm{SO}_{4}$ type water

$\mathrm{Ca}-\mathrm{SO}_{4}$ type water finds in the headscape of the Happoukuchi landslide and the Ishikura landslide. This type water involves the groundwater from drill holes and natural springs, its electrical conductivity is $321-1,063 \mu \mathrm{S} / \mathrm{cm}$. The stream waters collected from landslides are mainly $\mathrm{Ca}$ $-\mathrm{SO}_{4}$ type water.

(b) $\mathrm{Na}-\mathrm{SO}_{4}$ type water

$\mathrm{Na}-\mathrm{SO}_{4}$ water is high in electrical conductivity with $1,096-7,140 \mu \mathrm{S} / \mathrm{cm}$. It mainly distributes in the central part and the front of the Happoukuchi landslide and the A-block of the Utsunomata landslide. It finds from horizontal drainage holes, drill holes and collecting water well in the Happoukuchi landslide, and is natural spring in the A-block of the Utsunomata landslide. The water-rock experimental results indicated that the water quality resulted from mudstone experiments with various $\mathrm{pH}$ solution is $\mathrm{Na}$ $-\mathrm{SO}_{4}$ type water. This $\mathrm{Na}-\mathrm{SO}_{4}$ type water is formed by a composite function, dissolution of gypsum or anhydrite, oxidation of the sulfide (e.g. pyrite) contained in the mudstone and incongruent dissolution of rock forming minerals associated with cation exchange. Oxidation of sulfide is important process. Sulfides are oxidized by dissolved oxygen and sulphate is eluted into groundwater. The incongruent dissolution of rock forming minerals controls the $\mathrm{pH}$ of groundwater as $\mathrm{pH}$ buffer. The major processes are written as below:

$$
\mathrm{CaSO}_{4} \rightarrow \mathrm{Ca}^{2+}+\mathrm{SO}_{4}{ }^{2-}
$$




$$
\begin{aligned}
& 4 \mathrm{FeS}_{2}+15 \mathrm{O}_{2}+14 \mathrm{H}_{2} \mathrm{O} \rightarrow 4 \mathrm{Fe}(\mathrm{OH})_{3}+8 \mathrm{SO}_{4}{ }^{2-} \\
& +16 \mathrm{H}^{+} \\
& 2 \mathrm{NaAlSi}_{3} \mathrm{O}_{8}+2 \mathrm{H}^{+}+9 \mathrm{H}_{2} \mathrm{O} \rightarrow \mathrm{Al}_{2} \mathrm{Si}_{2} \mathrm{O}_{5}(\mathrm{OH})_{4} \\
& +2 \mathrm{Na}^{+}+4 \mathrm{H}_{4} \mathrm{SiO}_{4} \\
& \mathrm{CaAl}_{2} \mathrm{Si}_{2} \mathrm{O}_{8}+2 \mathrm{H}^{+}+\mathrm{H}_{2} \mathrm{O} \rightarrow \mathrm{Al}_{2} \mathrm{Si}_{2} \mathrm{O}_{5}(\mathrm{OH})_{4}+\mathrm{Ca}^{2+} \\
& \mathrm{Ca}^{2+}+\mathrm{Na} \text {-clay } \rightarrow \mathrm{Ca} \text {-clay }+\mathrm{Na}^{+}
\end{aligned}
$$

(c) $\mathrm{SO}_{4}-\mathrm{HCO}_{3}$ type water

$\mathrm{SO}_{4}-\mathrm{HCO}_{3}$ type water is subdivided into two type waters, one is $\mathrm{Na}-\mathrm{SO}_{4}-\mathrm{HCO}_{3}$ type water and the other is $\mathrm{Ca}-\mathrm{SO}_{4}-\mathrm{HCO}_{3}$ type water, $\mathrm{Na}-\mathrm{SO}_{4}-\mathrm{HCO}_{3}$ type water distributes in the headscarpe area of the Happoukuchi landslide and issues from the horizontal drainage hole. Its conductivity is $1,215-1,300 \mu \mathrm{S} / \mathrm{cm}$. This type water is generated by the mixing between $\mathrm{Na}-\mathrm{SO}_{4}$ type water from shallow and $\mathrm{Na}-\mathrm{HCO}_{3}$ type water from deep. $\mathrm{Na}-\mathrm{HCO}_{3}$ type water with high electrical conductivity will be generated by desulfuration, because organic matters existed in the sediments catalyzes sulphate reduction, sulphate decreases and even wholly is consumed, $\mathrm{HCO}_{3}{ }^{-}$increases with $\mathrm{pH}$ increasing.

$\mathrm{Ca}-\mathrm{SO}_{4}-\mathrm{HCO}_{3}$ type water finds at natural springs and streams in the landslide. Its electrical conductivity is $115-621 \mu \mathrm{S} / \mathrm{cm}$. This type water is mainly generated by mixing between $\mathrm{Ca}-\mathrm{SO}_{4}$ type water and $\mathrm{Ca}-\mathrm{HCO}_{3}$ type water.

(d) $\mathrm{Ca}-\mathrm{HCO}_{3}$ type water

$\mathrm{Ca}-\mathrm{HCO}_{3}$ type water mainly distributes in the dacitic pumice tuff area and Ishikura landslide. Its electrical conductivity is $115-439 \mu \mathrm{S} / \mathrm{cm}$. The chemical compositions of this groundwater are mostly originated from silicates weathering. When meteoric water permeates into ground, the water containing $\mathrm{CO}_{2}$ reacts with $\mathrm{Ca}$-plagioclase. $\mathrm{Ca}^{2+}$ leach into groundwater from the bedrock. The processes of water-rock interaction is written as below:

$$
\begin{aligned}
& \mathrm{CaAl}_{2} \mathrm{Si}_{2} \mathrm{O}_{8}+2 \mathrm{CO}_{2}+3 \mathrm{H}_{2} \mathrm{O} \rightarrow \\
& \mathrm{Al}_{2} \mathrm{Si}_{2} \mathrm{O}_{5}(\mathrm{OH})_{4}+\mathrm{Ca}^{2+}+2 \mathrm{HCO}_{3}{ }^{-}
\end{aligned}
$$

$\mathrm{Ca}$-plagioclase displays as the most easily weathered mineral of silicate. The process of above is slow, and the retention time of groundwater in rock is short. This type groundwater is low EC recognized as fresh water,

(e) $\mathrm{Na}-\mathrm{HCO}_{3}$ type water

$\mathrm{Na}-\mathrm{HCO}_{3}$ type water finds at the head part of the Ishikura landslide. Its electrical conductivity is 211 $-1,171 \mu \mathrm{S} / \mathrm{cm}$. This type water is formed by dissolu- tion of dolomite and silicate weathering associated with cation exchange.

It was reported that the electrical conductivity of groundwater from fresh landslide is 10 times or more higher than that of groundwater from old landslide and the surrounding landslide area in the Tertiary landslide area in Niigata Prefecture ${ }^{6}$. Electrical conductivities of groundwaters from the Happoukuchi landslide and the A block of the Utsunomata landslide are higher 5-10 times than those of groundwaters from the Ishikura landslide. Their water qualities are also very different. $\mathrm{Na}-\mathrm{SO}_{4}$ type, $\mathrm{Na}$ $-\mathrm{SO}_{4}-\mathrm{HCO}_{3}$ type, $\mathrm{Na}-\mathrm{HCO}_{3}-\mathrm{Cl}$ type and $\mathrm{Na}-\mathrm{Cl}-\mathrm{HCO}_{3}$ type waters are characterized in the Happoukuchi landslide and the A block of Utsunomata landslide. $\mathrm{Na}^{-} \mathrm{SO}_{4}$ type is dominant. Qualities of grondwaters are mainly $\mathrm{Ca}-\mathrm{HCO}_{3}$ type, $\mathrm{Na}-\mathrm{HCO}_{3}$ type and $\mathrm{Ca}$ $-\mathrm{SO}_{4}$ type waters in the Ishikura landslide (Fig. 7). Quality of groundwater in the landslide is related with activity of landslide under the same geological environment. It is likely that the more active the landslide, the higher the concentration of major components of groundwaters.

\section{Water-Rock Interaction}

Water-rock interaction is emphasized in the studies on the genesis of groundwater ${ }^{7212}$. Dissolution experiments was conducted and the role of dissolution in triggering landslide in the loess area was discussed ${ }^{13)}$. In order to understand the chemical change of groundwater of the Utsunomata landslide area, experiments on water-rock interaction were conducted. The rock specimen applied to the experiment of water-rock interaction is dark gray mudstone of the Taruda formation collected from the Happoukuchi landslide. It is made up of plagioclase, quartz, montmorillonite, kaolinite, dolomite and pyrite by the X-ray powder examination. The powdered mudstone was allowed to react with different $\mathrm{pH}$ solutions controlled by $\mathrm{HCl}$. The results of experiments are given in Table 2.

The experimental results indicated that major chemical components of the dissolved solution are influenced by rock/water ratio, $\mathrm{pH}$ of solution and reaction time. When rock/water ratio increases, compositions of $\mathrm{SO}_{4}{ }^{2-}, \mathrm{HCO}_{3}{ }^{-}, \mathrm{Na}^{+}, \mathrm{Ca}^{2+}$ and $\mathrm{Mg}^{2+}$ are increased by a certain percentage. As $\mathrm{pH}$ of solution changes from neutral to $4, \mathrm{Na}^{+}$almost 
Table 2 Chemical composition of dissolved solution of water-rock experiments

\begin{tabular}{|c|c|c|c|c|c|c|c|c|c|c|c|c|c|c|}
\hline No. & $\begin{array}{l}\text { Powdered } \\
\text { rocks } \\
\text { (g) }\end{array}$ & $\begin{array}{l}\text { Solution } \\
(200 \mathrm{ml})\end{array}$ & $\begin{array}{c}\mathrm{pH} \\
\text { (solution) }\end{array}$ & $\begin{array}{l}\text { Reaction } \\
\text { time(day) }\end{array}$ & $\begin{array}{c}\mathrm{pH} \\
\text { (dissolved } \\
\text { solution) }\end{array}$ & $\begin{array}{c}\text { E.C. } \\
(\mu \mathrm{s} / \mathrm{cm})\end{array}$ & $\begin{array}{c}\mathrm{Na}^{+} \\
(\mathrm{meq} / \mathrm{l})\end{array}$ & $\begin{array}{c}\mathrm{K}^{+} \\
(\mathrm{meq} / \mathrm{l})\end{array}$ & $\begin{array}{c}\mathrm{NH}_{4}^{+} \\
\text {(meq/) }\end{array}$ & $\begin{array}{c}\mathrm{Ca}^{2+} \\
(\mathrm{meq} / \mathrm{l})\end{array}$ & $\begin{array}{c}\mathrm{Mg}^{2+} \\
(\mathrm{meq} / \mathrm{l})\end{array}$ & $\begin{array}{c}\mathrm{Cl} \\
(\mathrm{meq} / \mathrm{l})\end{array}$ & $\begin{array}{c}\mathrm{SO}_{4}{ }^{2-} \\
(\mathrm{meq} / \mathrm{l})\end{array}$ & $\begin{array}{l}\mathrm{HCO}_{3}^{-} \\
(\mathrm{meq} / \mathrm{l})\end{array}$ \\
\hline 1 & 20 & $\begin{array}{c}\text { Distelled } \\
\text { water }\end{array}$ & 6.7 & 10 & 7.2 & 508 & 3.76 & 0.24 & 0.10 & 0.36 & 0.16 & 0.10 & 3.04 & 1.50 \\
\hline 2 & 20 & $\begin{array}{c}0.00001 \mathrm{~N} \\
\mathrm{HCl}\end{array}$ & 4.9 & 10 & 7.1 & 508 & 3.76 & 0.24 & 0.06 & 0.39 & 0.16 & 0.09 & 3.47 & 1.39 \\
\hline 3 & 20 & $\begin{array}{c}0.0001 \mathrm{~N} \\
\mathrm{HCl}\end{array}$ & 4.0 & 10 & 6.9 & 511 & 3.74 & 0.24 & 0.07 & 0.41 & 0.17 & 0.13 & 3.51 & 1.36 \\
\hline 4 & 20 & $\begin{array}{c}0.001 \mathrm{~N} \\
\mathrm{HCl}\end{array}$ & 3.1 & 10 & 7.0 & 578 & 4.18 & 0.28 & 0.06 & 0.56 & 0.24 & 0.81 & 3.26 & 1.32 \\
\hline 5 & 20 & $\begin{array}{c}0.01 \mathrm{~N} \\
\mathrm{HCl}\end{array}$ & 2.0 & 10 & 6.1 & 1130 & 5.13 & 0.50 & 0.09 & 3.09 & 1.58 & 7.53 & 2.39 & 0.32 \\
\hline 6 & 40 & $\begin{array}{c}\text { Distelled } \\
\text { water }\end{array}$ & 6.7 & 10 & 7.4 & 795 & 6.20 & 0.34 & 0.08 & 0.72 & 0.30 & 0.11 & 5.06 & 2.25 \\
\hline 7 & 40 & $\begin{array}{c}0.00001 \mathrm{~N} \\
\mathrm{HCl}\end{array}$ & 4.9 & 10 & 7.3 & 759 & 6.21 & 0.32 & 0.07 & 0.74 & 0.31 & 0.05 & 5.73 & 2.04 \\
\hline 8 & 40 & $\begin{array}{c}0.0001 \mathrm{~N} \\
\mathrm{HCl}\end{array}$ & 4.0 & 10 & 7.3 & 825 & 6.36 & 0.34 & 0.07 & 0.75 & 0.31 & 0.13 & 5.97 & 1.97 \\
\hline 9 & 40 & $\begin{array}{c}0.001 \mathrm{~N} \\
\mathrm{HCl}\end{array}$ & 3.1 & 10 & 7.3 & 821 & 6.74 & 0.37 & 0.08 & 0.87 & 0.37 & 0.82 & 5.18 & 1.93 \\
\hline 10 & 40 & $\begin{array}{c}0.01 \mathrm{~N} \\
\mathrm{HCl}\end{array}$ & 2.0 & 10 & 7.1 & 1462 & 8.68 & 0.61 & 0.11 & 3.36 & 1.58 & 7.67 & 5.11 & 1.43 \\
\hline 11 & 20 & $\begin{array}{c}\text { Distelled } \\
\text { water }\end{array}$ & 6.7 & 30 & 8.0 & 566 & 4.10 & 0.25 & 0.06 & 0.70 & 0.30 & 0.01 & 3.52 & 2.00 \\
\hline 12 & 20 & $\begin{array}{c}0.00001 \mathrm{~N} \\
\mathrm{HCl}\end{array}$ & 4.9 & 30 & 7.5 & 567 & 4.11 & 0.25 & 0.06 & 0.68 & 0.29 & 0.01 & 3.55 & 2.00 \\
\hline 13 & 20 & $\begin{array}{c}0.0001 \mathrm{~N} \\
\mathrm{HCl}\end{array}$ & 4.0 & 30 & 7.3 & 562 & 4.07 & 0.25 & 0.06 & 0.68 & 0.30 & 0.08 & 3.38 & 2.00 \\
\hline 14 & 20 & $\begin{array}{c}0.001 \mathrm{~N} \\
\mathrm{HCl}\end{array}$ & 3.1 & 30 & 7.3 & 661 & 4.41 & 0.31 & 0.07 & 1.19 & 0.55 & 0.75 & 4.21 & 1.68 \\
\hline 15 & 20 & $\begin{array}{c}0.01 \mathrm{~N} \\
\mathrm{HCl}\end{array}$ & 2.0 & 30 & 5.3 & 1206 & 5.13 & 0.47 & 0.11 & 4.03 & 2.08 & 7.54 & 4.12 & 0.18 \\
\hline
\end{tabular}

remains constant, whereas $\mathrm{SO}_{4}{ }^{2-}, \mathrm{Ca}^{2+}$ and $\mathrm{Mg}^{2+}$, gradually increase and $\mathrm{HCO}_{3}{ }^{-}$, gradually decreases. The lower the $\mathrm{pH}$ of solution, the more the ions of $\mathrm{SO}_{4}{ }^{2-}, \mathrm{Na}^{+}, \mathrm{Ca}^{2+}$ and $\mathrm{Mg}^{2+}$ elute to solution, especially $\mathrm{SO}_{4}{ }^{2-}$, $\mathrm{Ca}^{2+}$ nad $\mathrm{Mg}^{2+}$ are considerably increased. Concentrations of $\mathrm{SO}_{4}{ }^{2-}, \mathrm{Na}^{+}, \mathrm{Ca}^{2+}$ and $\mathrm{Mg}^{2+}$ are increased with increasing of reaction time.

Chemistry of shallow groundwater is generated by rock-water interaction. When meteoric water percolates into ground and reaches to bedrock, major dissolved components are eluted from bedrock through mineral dissolution and oxidation of sulfur compounds containing in the bedrock. Incongruent dissolution of rock forming minerals associated with cation exchange is important chemical process. Major chemical components of $\mathrm{SO}_{4}{ }^{2-}, \mathrm{HCO}_{3}{ }^{-}, \mathrm{Na}^{+}$, $\mathrm{Ca}^{2+}$ and $\mathrm{Mg}^{2+}$ are supplied to groundwater. Origin and evolution of groundwater are estimated by correlations among chemical components in groundwater ${ }^{14)}$. Correlations among $\mathrm{Ca}^{2+}$ and $\mathrm{SO}_{4}{ }^{2-}, \mathrm{Ca}^{2+}$ and $\mathrm{HCO}_{3}{ }^{-}, \mathrm{Na}^{+}$and $\mathrm{SO}_{4}{ }^{2-}, \mathrm{Na}^{+}$and $\mathrm{HCO}_{3}{ }^{-},\left(\mathrm{Ca}^{2+}+\right.$ $\left.\mathrm{Mg}^{2+}\right)$ and $\left(\mathrm{HCO}_{3}+\mathrm{SO}_{4}{ }^{2-}\right)$, and $\left(\mathrm{Na}^{+}+\mathrm{K}^{+}\right)$and $\left(\mathrm{HCO}_{3}+\mathrm{SO}_{4}{ }^{2-}\right)$ are dispersed in the Utsunomata landslide areas. These correlations indicated that different origin of groundwater, there is different characteristics of geochemistry. The correlation between

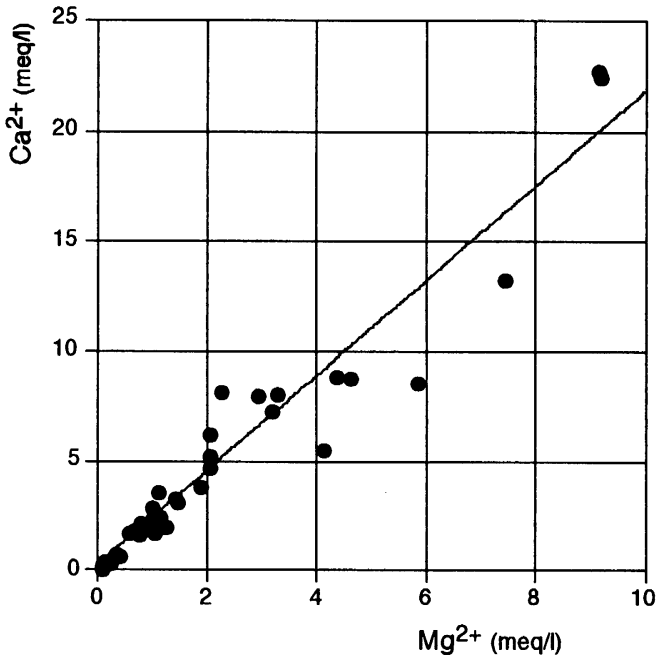

Fig. 4 Correlation between $\mathrm{Ca}^{2+}$ and $\mathrm{Mg}^{2+}$ in the groundwaters $\mathrm{Ca}^{2+}(\mathrm{meq} / \mathrm{l})=2.15 \mathrm{Mg}^{2+}(\mathrm{meq} / \mathrm{l})+0.2$

$\mathrm{Mg}^{2+}$ and $\mathrm{Ca}^{2+}$ is extremely positive(Fig. 4) with ratio $\mathrm{Mg}^{2+}(\mathrm{meq}): \mathrm{Ca}^{2+}(\mathrm{meq}) \cong 1: 2$. From the experimental results, the ratio of $\mathrm{Mg}^{2+}$ over $\mathrm{Ca}^{2+}$ is nearly equal to that of groundwaters (Fig. 5). In a major cation diagram (Fig. 6), all of groundwaters and dissolution experiments are plotted on a line having $\mathrm{Mg}^{2+}$ (meq) $: \mathrm{Ca}^{2}(\mathrm{meq}) \cong 1: 2$. Calcite veins are found in 


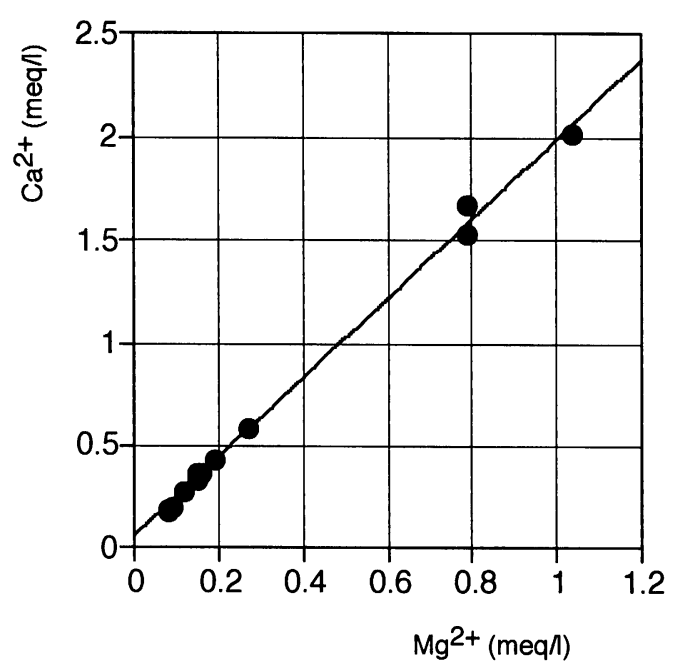

Fig. 5 A relation between $\mathrm{Ca}^{2+}$ and $\mathrm{Mg}^{2+}$ in the dissolution experiments of the mudstone of the Taruda formation $\mathrm{Ca}^{2+}(\mathrm{meq} / \mathrm{l})=1.93 \mathrm{Mg}^{2+}(\mathrm{meq} / \mathrm{l})+0.06$

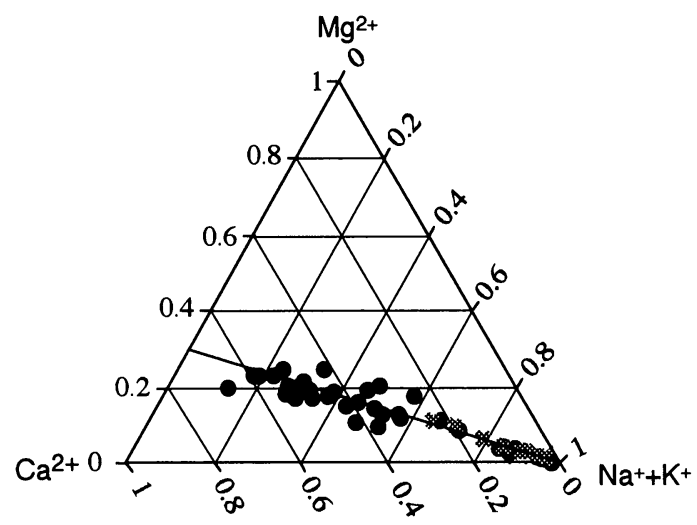

- groundwater dissolution experiments

Fig. $6\left(\mathrm{Na}^{+}+\mathrm{K}^{+}\right)-\mathrm{Ca}^{2+}-\mathrm{Mg}^{2+}$ diagram of groundwaters in the Utsunomata landslide area and dissolution experiments of the mudstone

cracks of mudstone in the Utsunomata landslide area and indicate that calcite is supersaturated in the aquifer of mudstone. Dissolutions of soluble sulphate minerals are related with the reaction among calcite and dolomite. C. A. J. Applelo and D. Postma ${ }^{15)}$ stated that dissolution of gypsum induces transformation of dolomite to calcite and produces waters with increase of $\mathrm{Ca}^{2+}, \mathrm{Mg}^{2+}$ and $\mathrm{SO}_{4}{ }^{2-}$ and decrease of alkalinity. In aquifer containing dolomite and calcite, if groundwater is equilibrium with both minerals, the following equation must exist.

$$
\mathrm{Ca}^{2+}+\mathrm{CaMg}\left(\mathrm{CO}_{3}\right)_{2} \rightarrow 2 \mathrm{CaCO}_{3}+\mathrm{Mg}^{2+}
$$

$$
\mathrm{K}=\left[\mathrm{Mg}^{2+}\right] /\left[\mathrm{Ca}^{2+}\right]=\mathrm{K}_{\mathrm{dol}} / \mathrm{K}_{\mathrm{cc}}{ }^{2}=0.8
$$

Dissolution of gypsum takes place according to

$$
\mathrm{CaSO}_{4} \rightarrow \mathrm{Ca}^{2+}+\mathrm{SO}_{4}{ }^{2-}
$$

Under same circumstances, precipitation of calcite facilitates dissolution of gypsum. When the equilibrium with calcite and dolomite is maintained, the ratio of $\left[\mathrm{Mg}^{2+}\right] /\left[\mathrm{Ca}^{2+}\right]$ must remain about 0.8 . However, the apparent state of supersaturation of calcite in groundwater of the Utsunomata landslide area influences the ratio of $\left[\mathrm{Mg}^{2+}\right]$ over $\left[\mathrm{Ca}^{2+}\right]$. The $\mathrm{Sl}_{\mathrm{cc}}=0.1$ and $\mathrm{Sl}_{\mathrm{dol}}=0$ are taken into account, then,

$$
\begin{aligned}
& {\left[\mathrm{Mg}^{2+}\right] /\left[\mathrm{Ca}^{2+}\right]=\mathrm{K}_{\mathrm{dol}} / \mathrm{K}_{\mathrm{cc}}{ }^{2}} \\
& =10^{-17.09} /\left[10^{-8.48+0.1}\right]^{2} \cong 0.5
\end{aligned}
$$

This is the ratio of $\left[\mathrm{Mg}^{2+}\right]$ over $\left[\mathrm{Ca}^{2+}\right]$ in groundwaters of the Utsunomata landslide area. The overall process of this function is as below.

$$
\begin{aligned}
& 3 \mathrm{CaSO}_{4}+\mathrm{CaMg}\left(\mathrm{CO}_{3}\right)_{2} \\
& \quad \rightarrow 2 \mathrm{CaCO}_{3}+2 \mathrm{Ca}^{2+}+\mathrm{Mg}^{2+}+3 \mathrm{SO}_{4}{ }^{2-}
\end{aligned}
$$

\section{Active faults and geopressured thermal water}

Geopressured thermal water mainly comes up through fractures along active faults. Ōki et $\mathrm{al}^{16)}$ pointed out that a considerable linear distribution of temperature and water chemistry anomalies of groundwater appeared along active faults in the geopressured hydrothermal system region and provide useful information in finding active fault.

In the Happoukuchi landslide, usually temperature of groundwater is $10-12{ }^{\circ} \mathrm{C}$, but the temperatures of No. 2, No. 3, No. 6 and No. 7 are higher $2-4.7^{\circ} \mathrm{C}$ than the mean temperature. The temperatures of No. 2 and No. 3 are $14.9^{\circ} \mathrm{C}$ and $16.2^{\circ} \mathrm{C}$, respectively. These anomalies of high temperature of groundwaters show a linear NEE trending distribution (Fig. 8). In water chemistry, $\mathrm{Cl}^{-}$concentration of groundwater also shows a linear distribution with NEE trending (Fig. 9), $\mathrm{Cl}^{-}$concentrations of No. 3, No. 6 and No. 7 are 4 . $15 \mathrm{meq} / 1,4.14 \mathrm{meq} / 1$ and $28.86 \mathrm{meq} / 1$, respectively. Water qualities of No. 7 and No. 6 are $\mathrm{Na}-\mathrm{HCO}_{3}-\mathrm{Cl}$ type and $\mathrm{Na}-\mathrm{Cl}-\mathrm{HCO}_{3}$ type waters, respectively. Linear distributions of temperature and $\mathrm{Cl}^{-}$concentration anomalies of groundwater image a NEE trending active fault.

Water temperatures of No. 33 and No. 37 are $13.2^{\circ} \mathrm{C}$ and higher $2.7^{\circ} \mathrm{C}$ than the mean temperature of groundwater in the Ishikura landslide. $\mathrm{Cl}^{-}$concentra- 


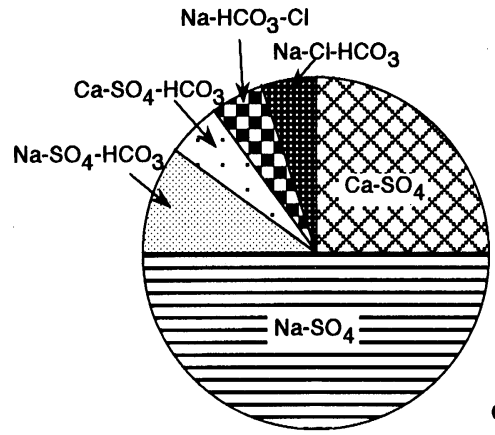

Happoukuchi Landslide

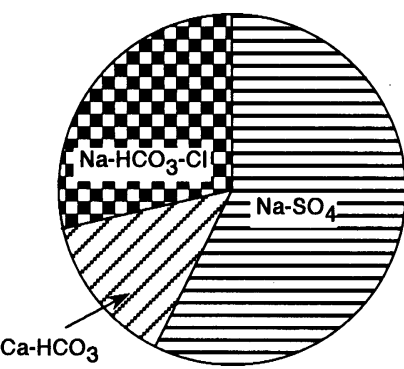

Utsunomata Landslide

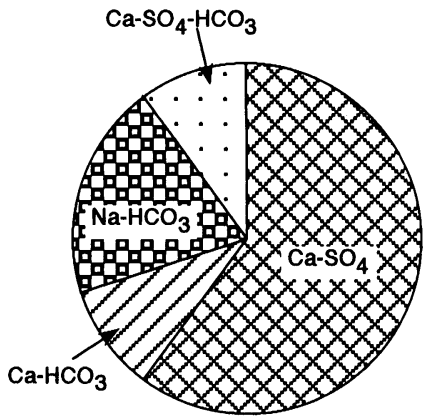

Ishikura Landslide

Fig. 7 Water types of groundwater in the Utsunomata landslide area

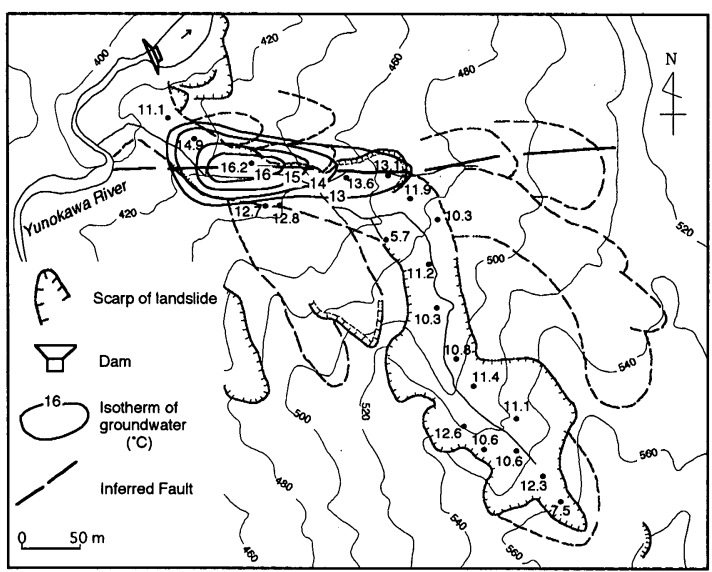

Fig. 8 Isotherm of groundwater in the Happoukuchi landslide, Niigata Prefecture

tion of No. 33 groundwater is $3.16 \mathrm{meq} / 1$ and indicates that this $\mathrm{Na}-\mathrm{HCO}_{3}$ type water is influenced by geopressured thermal water issued from deep. The distribution of these groundwaters with high temperature and high $\mathrm{Cl}^{-}$concentration suggests existence of NEE trending active fault. In the $A$ block of the Utsunomata landslide, distribution of $\mathrm{Na}-\mathrm{HCO}_{3}-\mathrm{Cl}$ type water also implies the existence of active fault through which geopressured thermal water is coming up.

\section{Conclusion}

Geopressured hydrothermal water is an important source of dissolved $\mathrm{NaCl}$ and $\mathrm{NaHCO}_{3}$ in the Utsunomata landslide area. This geopressured thermal water issues from deep through fractures along active faults. $\mathrm{Na}-\mathrm{Cl}-\mathrm{HCO}_{3}$ type and $\mathrm{Na}-\mathrm{HCO}_{3}-\mathrm{Cl}$ type

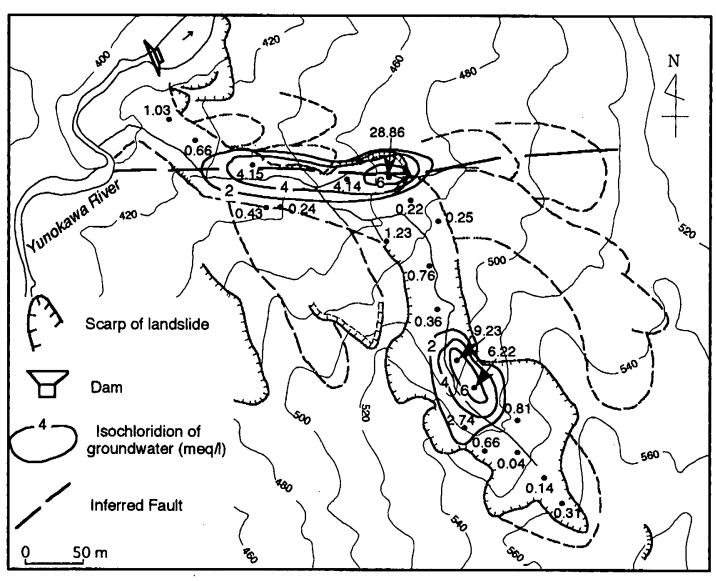

Fig. 9 Isochloridion of groundwater in the Happoukuchi landslide, Niigata Prefecture

groundwaters originated in geopressured thermal water distribute along active faults and cause higher temperature and $\mathrm{Cl}^{-}$concentration in groundwater. Three active faults are imaged by distribution of these anomalies of groundwaters in the study area. Landslides might be generated by activity of geopressured hydrothermal system. Monitoring of activity of groundwater in the geopressured type landslides region is useful for prevention of landslide movement and also provides important information for earthquake prediction.

The Ishikura landslide is a metastable landslide. Its groundwaters are characterized by $\mathrm{Ca}-\mathrm{HCO}_{3}$ type, $\mathrm{Na}-\mathrm{HCO}_{3}$ type and $\mathrm{Ca}-\mathrm{SO}_{4}$ type groundwaters with low electrical conductivity. The Happoukuchi landslide and the A block of the Utsunomata landslide are active landslides, their groundwaters are mainly char- 
acterized by $\mathrm{Na}-\mathrm{SO}_{4}$ type, $\mathrm{Na}-\mathrm{SO}_{4}-\mathrm{HCO}_{3}$ type, $\mathrm{Na}$ $-\mathrm{HCO}_{3}-\mathrm{Cl}$ and $\mathrm{Na}-\mathrm{Cl}-\mathrm{HCO}_{3}$ type waters, electrical conductivities and concentrations of major components of groundwater are 5-10 times higher than those of the Ishikura landslide. The more active the landslide, the higher the concentration of major components of groundwaters. Landslide stability can be evaluated by geochemistry of groundwater.

\section{Acknowledgments}

The authors would like to thank Mr. K. Suzuki of the Research Institute for Hazards in Snowy areas, Niigata University for his kind help in the fieldwork. We would like to make a grateful acknowledgment to Mr. N. Mizutani of Nissaku Co. Ltd. for providing the landslide information, that is very precious to proceed this study.

\section{References}

1) Oki, Y., Sato, O. and Aoki, S. (1992): The earthquake and landslide generated by the geopressured hydroth ermal system in the Northern Fossa Magna Region. Chikyu Monthly, Special Issue No. 5, pp 121-125.

2 ) Billard, A., Muxart, T., Derbyshire, E., Wang J. T. and Dijkstra, T. A. (1993): Landsliding and Land Use in the Loess of Gansu Province, China. Zeitschchrift für Geomorphologie, Suppl. -bd. 87, 117-131pp.

3) Oki, Y. (1994): Earthquake Prediction and Groundwater, Annual Report of the Institute of Industrial Geological Science, No. 5, pp11-21.

4) Okki, Y., Xu, H., Watanabe, N., Suzuki, K. and Sato, O. (1995): The seismic intensity distribution of the 1995 Northern Niigata earthquake suggesting the buried earthquake fault. Chikyu Monthly, Vol. 17, No. 12, pp766-773.

5 ) Takeuchi, K. and Kato, H. (1994): Geology of the TAKADA-TOBU district. Quadrangle series, Scale 1: 50000 , Niigata (7), No. 6.

6) Sato, O. and Aoki, S. (1990): Characteristic properties of groundwaters from fresh and old landslides in the Tertiary landslide area in Niigata Prefecture. Jour. nal of Japan Landslide Society, Vol. 27, No. 1, pp27-33.

7) Garrels R. M and Christ C. L. (1965): Solutions, Minerals and Equilibria. Freeman and Cooper. 450pp.

8) Stumm W. and Morgan J. J. (1970): Aquatic Chemis try. Wiley-Interscience. 583pp.

9) Sato, O. (1993): The investigation method of groundwater in the landslide, - field investigation and data treatment - (1). Technology of landslide, Vol. 20, No. $1, \mathrm{pp} 11-23$.

10) Sato, O. (1993): The investigation method of groundwater in the landslide, - field investigation and data treatment - (2). Technology of landslide, Vol. 20, No. 2, pp18-28.

11) Sato, O. (1993): The investigation method of groundwater in the landslide. - field investigation and data treatment - (3). Technology of landslide, Vol. 20, No. 3, pp16-26.

12) Watanabe, N., Washizu, F. Ōki, Y. and Sato, O. (1995): Chemical characteristics of groundwaters from the Matsunoyama landslide area, Niigata Prefecture. Journal of Japan Landslide Society, Vol. 32, No. 3, pp32-40.

13) Muxart, T., Billard, A., Andrieu, A., Derbyshire, E., and Meng, X. (1995): Changes in Water Chemistry and Loess Porosity with Leaching: Implications for Collapsibility in the Loess of North China. Genesis and Properties of Collapsible Soils. Kluwer Academic Publishers. 313-331pp.

14) Isagai, K., Isagai, K., Iwasaki, M. and Takagi, T. (1990): Distinction of Chemical Composition in Groundwater by Difference Type of Landslides. Journal of Japan Landslide Society, Vol. 26, No. 4, pp16-28.

15) Appelo C. A. J. and Postma D (1992): Geochemistry, groundwater and pollution. A. A. Balkema.

16) Öki, Y., Xu, H., Watanabe, N., Suzuki, K. and Sato, O. (1996): Geopressured Hydrothermal Anomalies Appeared in the Niigata Plain Indicating Buried Active Faults Generated Destructive Earthquakes. Abstracts of the IASPEI Regional Assembly in Asia. pp202-203.

（原稿受理日 平成 9 年 2 月 17 日） 
含水比による剪断層構造の変化および剪断層の透水性

「地すべり」Vol. 34, No. 2（通巻第 130 号） pp. 1 8, 1997 年（平成 9 年）9月

岸本良次郎

1. 火山灰土の最適含水比 Wopt $\%$ と Wopt $-10 \%$, Wopt $+10 \%$ の試料を用いて一面剪断試験により剪断層を作 り，その側面の構造を写真により観察した。前 2 者では固体的性格で，あと 1 者では流体的性格の構造であった。 2. 火山灰土, カオリナイトに対する一面剪断試験により, 突固め, 垂直圧力載荷, 剪断破壊時, クリープ (変 位 $15 \mathrm{~mm}$ ）の諸段階の剪断層で作り, その透水係数を測定した。剪断層が形成されると, その方向の透水係数 は，層と直角方向の透水係数より約 1 桁大きくなった。

善徳地すべりにおける地下漫食と地すべり移動の関係

「地すべり」Vol. 34, No. 2（通巻第 130 号）pp. 9 16, 1997 年（平成 9 年）9月

古谷 元，佐々恭二，福岡 浩, 日浦啓全

本研究は, 結晶片岩地すべりの移動の原因のひとつに地下浸食が大きな因子として働いているという考えのも と, 徳島県三好郡西祖谷山村にある善徳地すべり地の湧水点で地下浸食されて流出する土砂の観測を行い, 地下 浸食と地すべりの移動の関係について検討した。その結果，涌水点から降雨の他に地すべりの移動の影響も受け た土砂が流出しており，地すべりの移動が降雨量と流出土砂量の関係をばらつかせる原因であることが明らかに なった。

\section{北淡町轟木地区における斜面変動観測の解析}

「地すべり」Vol. 34, No. 2 (通巻第 130 号) pp. 17〜24, 1997 年（平成 9 年） 9 月

新井場公德, 末峯 章, 坂本 哲

北淡町藉木地区の風化花崗閃緑岩斜面における連続伸縮計観測の結果を解析し，観測された斜面変動は降雨に

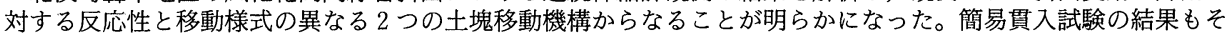
の結果と調和的であった。

Geochemistry of Groundwaters in the Utsunomata Landslide Area, Maki Village, Higashikubiki District, Niigata Prefecture

「地すべり」Vol. 34, No. 2（通巻第 130 号） pp. 25〜34, 1997 年（平成 9 年）9 月

XU Huilong, Yasue ŌKI, Osamu SATO and Hideki WATANABE

宇津俣地すべり地帯は新潟県南西部に位置する。地すべり地帯地下水の水温・水質調查を実施したところ, 水 温・水質異常地帯は伏在活断層の存在を強く支持している。塩素イオン濃度の高い地下水は活断層にそって分布 していることが確認された。活動的な地すべり地域においての地下水の主要成分濃度は高い值を示している。活 動している地すべり地域では地下水は高濃度の $\mathrm{Na}-\mathrm{Cl}-\mathrm{HCO}_{3}$ 型, $\mathrm{Na}-\mathrm{HCO}_{3}-\mathrm{Cl}$ 型と $\mathrm{Na}-\mathrm{SO}_{4}$ 型が主なものであ る。安定あるいは準安定的な地すべり地域では地下水は低濃度の $\mathrm{Ca}-\mathrm{HCO}_{3}$ 型, $\mathrm{Na}-\mathrm{HCO}_{3}$ 型と $\mathrm{Ca}-\mathrm{SO}_{4}$ 型で特徵 づけられている。

Spencer の一般分割法についての考察

「地すべり」Vol. 34, No. 2（通巻第 130 号） pp. 35〜 41，1997 年（平成 9 年）9 月 古谷 保

斜面安定解析法のひとつに, 1973 年に発表された Spencer の一般分割法がある。1973 年の Spencer 法のモーメ ント平衡式について考察を行い，この式がすべり面の始点を中心として不静定内力のモーメントを積算したもの であることを示した。また, 1967 年及び 1973 年の Spencer 法と比較して，より一般的なモーメント平衡式を提案 し，その力学的意味と式の特性，プログラミング上の優劣等について論じた。

道路建設に伴う四国の中央構造線沿いの地すべりの特性

「地すべり」Vol. 34, No. 2 (通巻第 130 号) pp. 42 49, 1997 年（平成 9 年）9月

矢田部 龍一, 八木則男, 佐藤修治, 長谷川修一

本報告は四国の中央構造線に沿った道路建設に伴い発生した地すべり地の特性について検討を行ったものであ る。その結果, 地すべりは大半が切土に伴う崩積土のすべりであり, 規模は比較的小規模なものが多く, また, 中央構造線の断層破砕帯の地すべり地の粘性土のせん断抵抗角は小さく，難工事となりやすいことがわかった。

台湾, 中部横貫公路地すへり土の残留および回復強度特性

「地すべり」Vol. 34, No. 2 (通巻第 130 号) pp. $50 \sim 56,1997$ 年（平成 9 年） 9 月

宜保清一, 陳 信雄, 江頭和彦, 林 義隆, 周 亜明

本論文は，大規模な再活動型地すべりである台湾の中部横貫公路地すべり土の大变位せん断挙動，残留強度， および回復強度について検討したものである。地すべり域の地質は主として新第三紀中新世端芳層群の頁岩から なる。試料は，粘土含量が低く，低塑性であり，石英を主として，雲母，緑泥石，長石を含有する。強度測定は， $420 \mu \mathrm{m}$ フルイ通過スラリー試料について, リングせん断試験機を用い, 所定の垂直応力 $\left(\sigma_{\mathrm{n}}=50 \sim 300 \mathrm{kPa}\right)$ の 下で正規圧密せん断を行った。排水条件下で, まず完全軟化強度を測定し, $700 \mathrm{~mm}$ 程度の大変位を与えて残留強 度を測定した。残留強度測定後は供試体を再圧密し，再びせん断して強度の回復特性を調べた。

完全軟化強度定数は $\mathrm{C}_{\mathrm{sf}}=4.6 \mathrm{kPa}, \phi_{\mathrm{sf}}=35.3^{\circ}$ であった。残留強度定数は, 強度包絡線が湾曲化傾向を示したの で, 有効垂直応力レベル別に $C_{r}=0$ として $\phi_{\mathrm{r}}$ を求めた。 $\sigma_{\mathrm{n}}{ }^{\prime}=50 \sim 150 \mathrm{kPa}$ に対して $\phi_{\mathrm{r} 1}=31.2^{\circ}, \sigma_{\mathrm{n}}{ }^{\prime}=200 \sim 300$ $\mathrm{kPa}$ に対して $\phi_{\mathrm{r} 2}=25.4^{\circ}$ となった。再圧密による強度の回復については, $\sigma_{\mathrm{n}}{ }^{\prime}=200 \sim 300 \mathrm{kPa}$ では回復が認められ

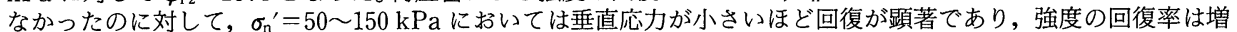
大したが, その強度は完全軟化強度のレベルに至らなかった。これらの結果は, 再活動型地すべりの再発生機構 を解明する上で重要である。

\section{土の中距離剪断試験試作機の構造と性能の概要}

「地すべり」Vol. 34, No. 2 (通巻第 130 号) pp. 57〜61, 1997 年（平成 9 年）9月 岸本良次郎, 吉田 純

クリープ領域における剪断層の構造を調べるため, 剪断箱の長さ約 $60 \mathrm{~cm}$, 与え得る剪断変位 $0 \sim 60 \mathrm{~cm}$ の一面 剪断試験機を試作した(中距離剪断試験機と仮称する)。この試験機の性能試験を行なった結果, 実際に種々の変 位を経たクリープを作り得，また試料中の長さ方向の変形はほほ均等であった。これにより試作の目的を達成し た。 